\title{
Biological characteristics and lytic effectiveness of phages isolated from domestic wastewater against indigenous Salmonella spp.
}

\begin{tabular}{lll}
\hline Paper received: 13.12 .2017 & Revised received: 23.03 .2018 & Re-revised received: 25.07 .2018 \\
\hline
\end{tabular}

\section{Authors Info}

S. Budiarti ${ }^{1}$, R.N. Sunarti' S.A.P. Listya ${ }^{1}$ and I. Rusmana

${ }^{1}$ Department of Biology, Faculty of Mathematics and Natural Science, Bogor Agricultural University, Bogor, 16680, West Java, Indonesia

${ }^{2}$ Faculty of Science and Technology, State Islamic University of Raden Fatah, Palembang, 30151, Indonesia

*Corresponding Author Email : s_budiarti@yahoo.com

\section{Edited by}

Dr. Norshuhaila Mohamed Sumar

Reviewed by

Dr. Sudip Barat

Dr. R. B. Raizada

\section{Abstract}

Aim : This study was carried out to isolate and study the effectiveness of lytic phage from domestic wastewater to reduce the population of Salmonella spp. in patients suffering from diarrhea and to characterize biological phages.

Methodology : The lytic phages from several domestic wastewater were identified using a transmission electron microscope to know morphological phages. After identifying the molecular weight protein by sodium dodecyl sulphate-polyacrylamide gel electrophoresis, to know the effectiveness, the lytic phages were infected to Salmonella spp. from diarrheal disease patients and non-pathogenic Escherichia coli. Phage stability on thermal, $\mathrm{pH}$, and buffer was then analyzed to determine the biological characteristics.

Results : Three lytic phages (F-SB1, F-SB2, and F-SB3), successfully isolated from domestic wastewater, showed an icosahedral head with a short or long tail as their morphological characteristic These phages were morphologically similar to the phages of family Siphoviridae Myoviridae and Podoviridae. The three isolated lytic phages were stable at $27^{\circ} \mathrm{C}$ to $37^{\circ} \mathrm{C}$ $\mathrm{pH}$ 4-7 in sodium magnesium buffer and effectively decreased the population of Salmonella spp., however could notlyse E. coli.

Interpretation: All the isolated lytic phages in this
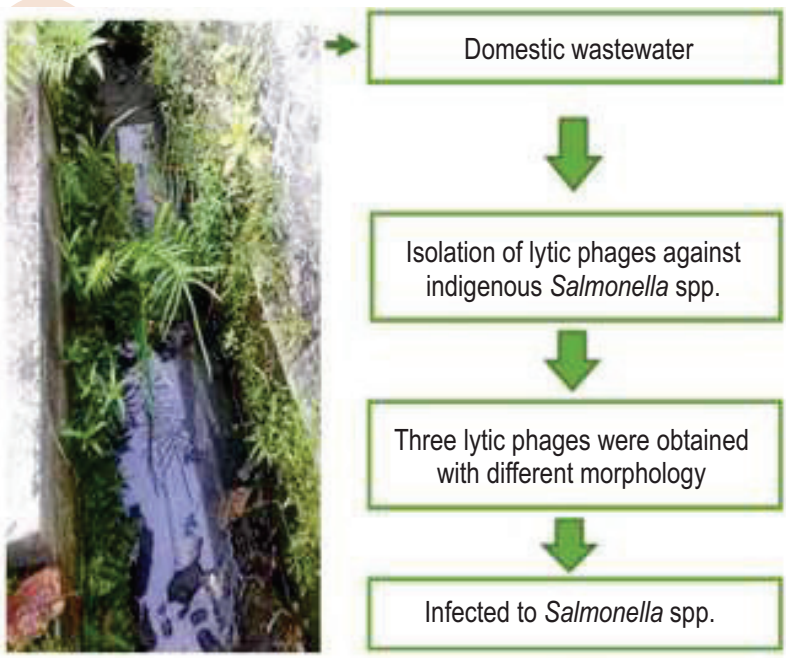
study can contribute as cocktail phages in decreasing the population Salmonella spp.

Key words: Antibiotic resistant, Domestic wastewater, Lytic phages, Salmonellosis, Salmonella spp.

How to cite : Budiarti, S., R.N. Sunarti, S.A.P. Listya and I. Rusmana: Biological characteristics and lytic effectiveness of phages isolated from domestic wastewater against indigenous Salmonella spp. J. Environ. Biol., 40, 53-60 (2019). 


\section{Introduction}

Salmonella spp. is a Gram-negative rod-shaped bacterium that belongs to family Enterobacteriaceae. Salmonella spp. can be found in several environments, including gills and intestines of animal (Toroglu et al., 2009). All the strain of Salmonella spp. have been reported as important pathogens in human and animals (Budiarti et al., 1991; Hoelzer et al., 2011; Kuhn et al., 2012; Eng et al., 2015; Bertelloni et al., 2016). Salmonella spp. are medically important foodborne pathogens, and one of the major cause of human and animal diseases. Salmonella species can cause foodborne diseases in humans. In Japan, there were 1505 cases of $S$. oranienburg infection in children due to contamination from snack semi-dry cuttlefish (Miyakawa et al., 2006). Ao et al. (2015) reported that Salmonella spp. is a key global cause of salmonellosis, which causes nontyphoidal diseases, such as diarrhea. There are 93.8 million reported cases of gastroenteritis around the world due to Salmonella species, causing 155,000 diarrheal deaths each year (Majowicz etal., 2010).

Many Salmonella spp. have been reported to be resistant to various antibiotics or antimicrobial agents. In Indonesia, they are resistant to antibiotics, including ampicillin, trimethoprimsulfamethoxazole, chloramphenicol, tetracycline, cephalothin, ceftriaxone, norfloxacin, ciprofloxacin, erythromycin and streptomycin (Tjanadi et al., 2003; Kusumaningrum et al., 2012). In other countries, it has been also reported that Salmonella spp. are resistant to ceftiofur, gentamicin, nalidixic acid, enrofloxacin, amoxicillin and nitrofurantoin (Matias et al., 2015; Ejo et al., 2016). Alternative approaches to control the emergence of antibiotic resistance in bacteria are urgently needed. It has been reported that phage cocktails are effective in reducing the population of EPEC K1.1 (Arivo et al., 2016), Listeria monocytogenes (Guenther et al., 2009), Enterobacter sakazaki (Zuber et al., 2008), Salmonella sp. (Turki et al., 2012) and S. enteritidis (Hungaro et al., 2013).

Several phages have been found in river water (Kusmiatun et al., 2015), domestic wastewater (Arivo et al., 2016), wastewater from local dairy farm (Nugroho et al., 2016), wastewater of poultry processing industries (Quiroz et al., 2016), marine and terrestrial environments (Doss et al., 2017) that can lyse pathogenic bacteria. It can be used against antibiotic resistant bacterial fish pathogen (Prasad et al., 2011; Dinkar et al., 2017). The potential of using lytic phages in nanotechnology and nanomedicine is expected to solve antibiotic resistance issues. In recent years, application of phages as a nanotechnology to control bacterial pathogens has received new interest. Phages are safe, natural and highly targeted antibacterial agents that specifically kill bacteria and can be targeted to kill human pathogens (Sartika et al., 2012). As phages have different morphology, there is an interest in characterizing the morphology and studying the effectiveness of phages to control Salmonella population. It is also important to study the biological characteristics of the phages because environmental factors such as $\mathrm{pH}$, temperature and buffer may destroy the elemental structures such as head, tail, protein, and change the DNA structure which can affect the production of phages.

Wastewater, which is commonly contaminated by Salmonella spp., is a frequent source of food contamination. The morphological and biological properties of large group of phages isolated from urban sewage have been reported by Kurek et al. (2016). However, there is no information about biological characteristics and effectiveness of indigenous lytic phages isolated from domestic wastewater to lyse Salmonella spp. present in patients suffering from diarrhea. In view of the above, this study was conducted to isolate the lytic phages of indigenous Salmonella spp. and their ability to reduce the population of Salmonella spp.

\section{Materials and Methods}

Isolation and visualization of Iytic phages: Domestic wastewater were of collected from seven different locations in Dramaga, Bogor, Indonesia were used as sources of phage isolates. Three bacterial isolates of Salmonella spp. (S1, S2 and S3), used as hosts in this research, were isolated from 200 samples of diarrhea patients in the Laboratory of Animal Biotechnology and Biomedical, Research Center of Biological Resources, Bogor Agricultural University. Approximately, $1 \mathrm{ml}$ of domestic wastewater sample was diluted in $9 \mathrm{ml}$ of nutrient broth medium and centrifuged at $4000 \mathrm{x} \mathrm{g}$ for $30 \mathrm{~min}$. The supernatant was filtered using filter membranes $\varnothing=0.45 \mu \mathrm{m}$ (Sartorius, Gottingen, Germany). Approximately, $4.5 \mathrm{ml}$ of filtrate was mixed with $0.5 \mathrm{ml}$ of Salmonella culture. $\left(10^{8} \mathrm{cfu} \mathrm{ml}^{-1}\right)$. The suspensions were incubated in a waterbath shaker (Certomat WR) for 24 hrs at $37^{\circ} \mathrm{C}$. The culture was centrifuged at $2800 \mathrm{xg}$ for $20 \mathrm{~min}$ at $4^{\circ} \mathrm{C}$. Approximately, $3 \mathrm{ml}$ of the supernatant was filtered using a filter membrane $(\varnothing=0.22 \mu \mathrm{m})$. The plaque assay was selected by the double layer agar method. About $100 \mu$ lof filtrate was added to $100 \mu$ l of Salmonella culture and incubated at $37^{\circ} \mathrm{C}$ for $30 \mathrm{~min}$. The suspensions were added to $5 \mathrm{ml}$ soft agar $\left(47^{\circ} \mathrm{C}\right)$ and poured into nutrient agar medium. The plates were incubated at $37^{\circ} \mathrm{C}$ for $24 \mathrm{hrs}$.

The phages were quantified by double layer method and measured by counting the number of plaque forming units $\left(\mathrm{pfu} \mathrm{ml}^{-1}\right)$. A transmission electron microscope was used to observe the morphology of the phages. Approximately, $10 \mu$ l of stock solution of phage was dropped onto the grid for $30 \mathrm{sec}$ and then dried with filter paper. About $5 \mu \mathrm{l}$ of $2 \%$ uranyl acetate solution was also dropped onto the grid for $1 \mathrm{~min}$ and then dried with filter paper for $60 \mathrm{~min}$. The dried specimens were placed on the holder and were observed with TEM JEOL JEM-1010 at the Eijkman Institute for Molecular Biology, operated at $80 \mathrm{kV}$ at a magnification of $80000 x-100000 x$.

Identification of phage proteins: Phage protein analysis was carried out by mixing a stock of sample buffer $(2 \mathrm{ml}$ mercaptoethanol, $4 \mathrm{ml}$ glycerol, $0.3 \mathrm{~g}$ Tris, $2 \mathrm{ml}$ bromophenol blue $0.1 \%$ at $\mathrm{pH} 6.8$ ) and $0.92 \mathrm{~g}$ of sodium dodecyl sulfate with stock 
phage. The molecular weights of the phage proteins were analyzed by sodium dodecyl sulphate- polyacrylamide gel electrophoresis (SDS-PAGE) with 12\% acrylamide (Laemmli, 1970).

Effectiveness of Salmonella spp. lytic phages: Lytic phage suspensions were tested in Salmonella S1, Salmonella S2, Salmonella S3 and non-pathogenic E. coli. The test was conducted using a double layer agar technique. Approximately, $100 \mathrm{ml}$ of Salmonella spp. culture $\left(10^{8} \mathrm{cfu} \mathrm{m}^{-1}\right)$ grown in nutrient broth medium was centrifuged at $2800 \mathrm{xg}$ at $4{ }^{\circ} \mathrm{C}$ for $30 \mathrm{~min}$ with three replications. Both controls (pellet without phage) and treatments (pellet with phage $10^{4} \mathrm{pfu} \mathrm{m}^{-1}$ and $3 \times 10^{4} \mathrm{pfu} \mathrm{m}^{-1}$ ) were incubated at $37^{\circ} \mathrm{C}$ for $30 \mathrm{~min}$. Each treatment was added to $50 \mathrm{ml}$ of nutrient broth medium and incubated at $37^{\circ} \mathrm{C}$. The $\mathrm{OD}_{600 \mathrm{~nm}}$ value of each culture was determined every hour.

Stability analysis of lytic phages: Stability of lytic phage was analyzed at different temperature $\left(27^{\circ} \mathrm{C}, 37^{\circ} \mathrm{C}, 45^{\circ} \mathrm{C}, 55^{\circ} \mathrm{C}\right.$ and $\left.60^{\circ} \mathrm{C}\right)$ and $\mathrm{pH}(4,5,7,9$ and 11$)$. Nutrient broth medium was used as a control. The purified plaque was mixed with $3 \mathrm{ml}$ of $25 \%$ Ringer buffer, $3 \mathrm{ml}$ of sodium magnesium buffer and $3 \mathrm{ml}$ of phosphate buffer saline and then incubated for $10 \mathrm{~min}$ at room temperature. The suspensions were then centrifuged at $4^{\circ} \mathrm{C}$ and filtered through $0.45 \mu$ filter membrane. The centrifugation containing supernatant of phage $\left(10^{6} \mathrm{pfu} \mathrm{m}^{-1}\right)$ was taken and refiltered using a $0.22 \mu \mathrm{l}$ filter membrane. The stability of phages to temperature, $\mathrm{pH}$ and buffers were determined by platting it using double layer agar technique.

Statistical analysis: All data in this study were determined by the means value of replicates in each analysis. The means of replicates in analysis of effectiveness of lytic phages, stability of Iytic phages, and stability of lytic phages at different buffer, temperature and $\mathrm{pH}$ were analyzed by standard deviation using MicrosoftExcel.

\section{Results and Discussion}

In the present study, out of seven sampling areas, only one area DWA3 showed the presence of Salmonella lytic phages (Table 1). Salmonella spp. were found in wastewater in several countries such as Mediterranian (Baudart et al., 2000), Abidjan (Julien et al., 2014), Nigeria (Dickson et al., 2016), France, Spain, Finland, Morocco, Mexico and USA (Boulani et al., 2017). The presence of four lytic phages that were capable of infecting Salmonella enterica was reported in approximately $66.67 \%$ of

Table 1: Sources of phage

\begin{tabular}{llll}
\hline $\begin{array}{l}\text { Sources of phage } \\
\text { (area) }\end{array}$ & $\begin{array}{l}\text { Amount of sample } \\
(\mathbf{x} 100 \mathrm{ml})\end{array}$ & \multicolumn{2}{c}{ Phage isolation results (host Salmonella spp.) } \\
\cline { 2 - 4 } & 3 & - & Salmonella S1 \\
\hline DWA 1 & 2 & - & - \\
DWA 2 & 2 & $+($ F-SB1) & $+($ F-SB2) \\
DWA 3 & 3 & - & - \\
DWA 4 & 2 & - & - \\
DWA 5 & 2 & - & - \\
DWA 6 & 2 & - & - \\
DWA 7 & 2 & -
\end{tabular}

DWA: Domestic waste water area; $(-)$ phages absent and $(+)=$ phages present
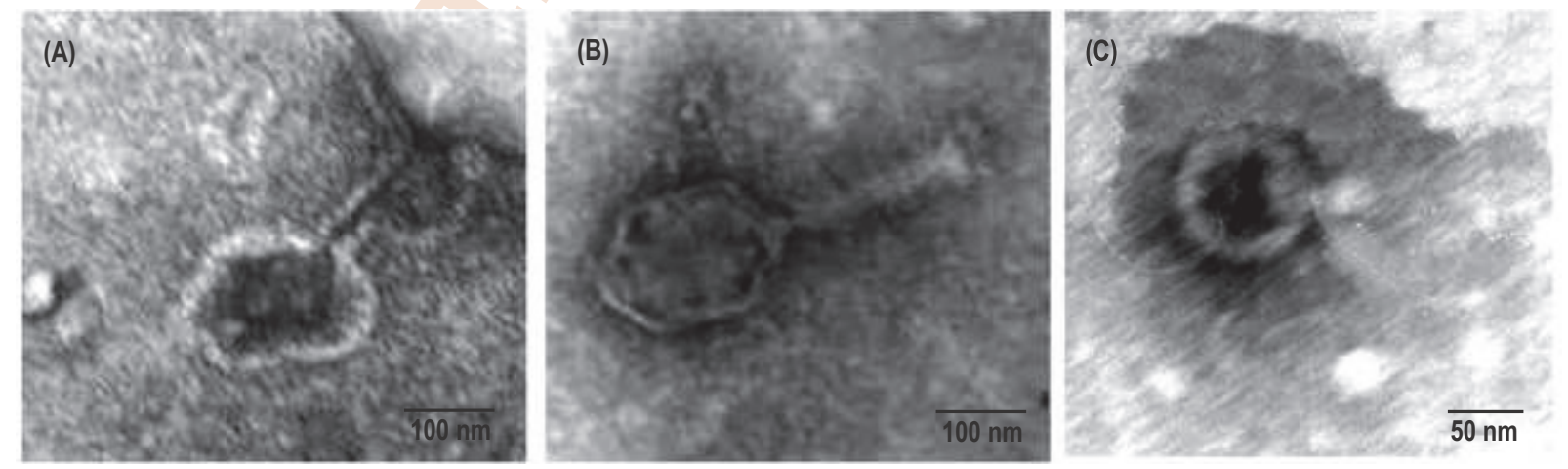

Fig. 1 : Morphology of phages: F-SB1 (A); F-SB2 (B) and F-SB3 (C) 
(A)

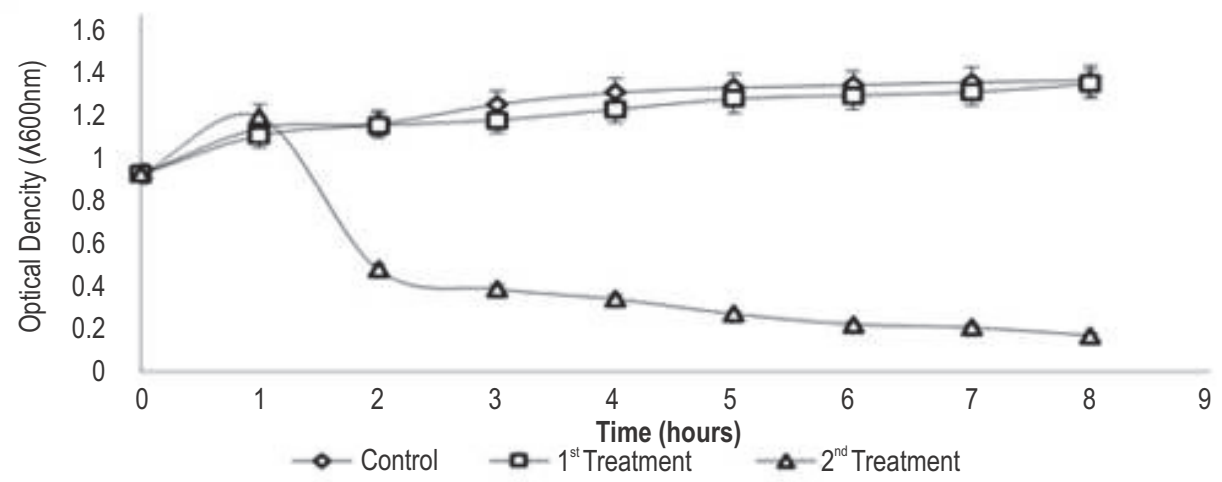

(B)

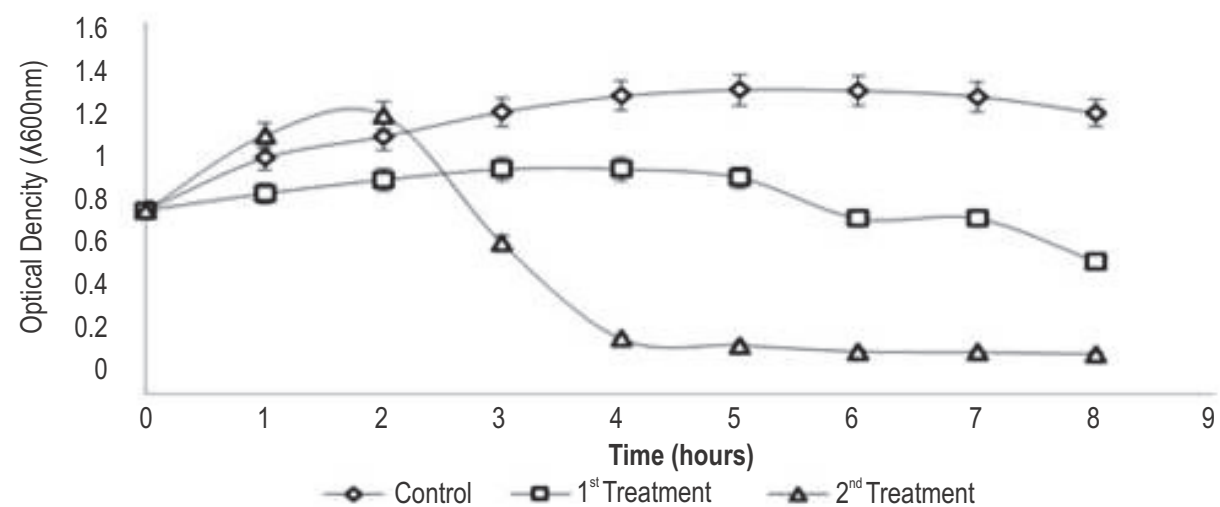

(C)

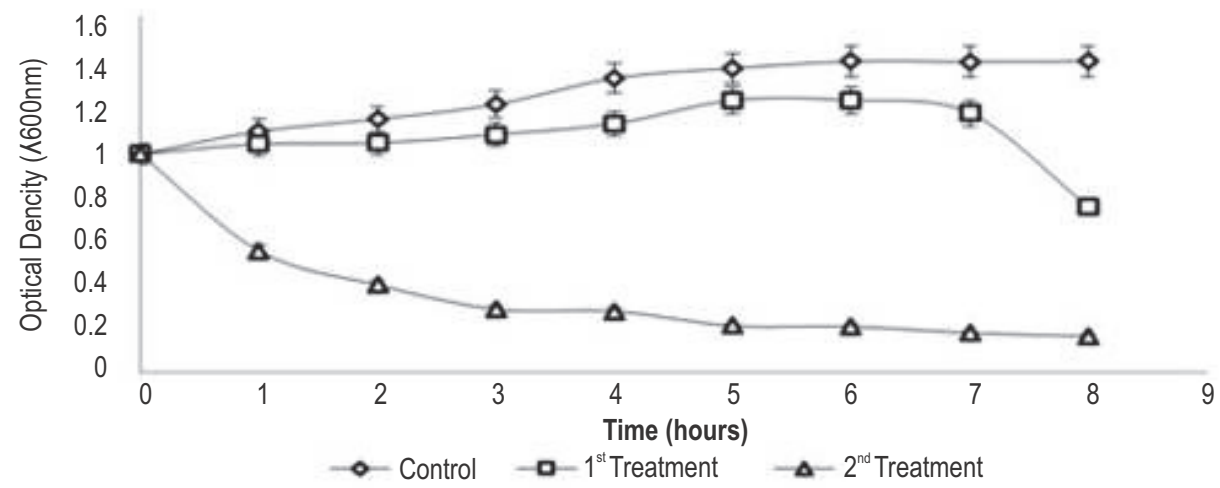

Fig. 2 : Effectiveness of lytic phages F-SB1, F-SB2, and F-SB3 to lyse Salmonella S1 (A), S2 (B), and S3 (C) cells incubated at $37^{\circ} \mathrm{C}$. Control: Salmonella spp. without phages, $1^{\text {st }}$ treatment: Salmonella spp. + phages $\left(10^{4} \mathrm{pfu} \mathrm{ml}^{-1}\right), 2^{\text {nd }}$ treatment: Salmonella spp. + phages $\left(3 \times 10^{4} \mathrm{pfu} \mathrm{ml}^{-1}\right)$.

wastewater from poultry processing industry in PichinchaEcuador (Quiroz et al., 2016). Phages are abundant in aquatic environment and play an important role in controlling their host population (Doss et al., 2017). Phages are only able to infect and reproduce in a suitable host, but they are not capable of replicating without a host cell. In Indonesia, it has been discovered that lytic phages can lyse pathogenic bacteria, i.e., Bacillus pumilus (Kusmiatun et al., 2015), EPEC contaminated food and water (Arivo et al., 2016) and Staphylococcus aureus (Nugroho et al., 2016).

The presence of three lytic phages (F-SB1, F-SB2 and FSB3) in the samples were indicated by a clear zone or plaque formed in agar plate. The plaque formed from each Salmonella spp. isolate had different concentration and diameters. The concentration of phage F-SB1, F-SB2, and F-SB3 were 33600 pfu 
(A)

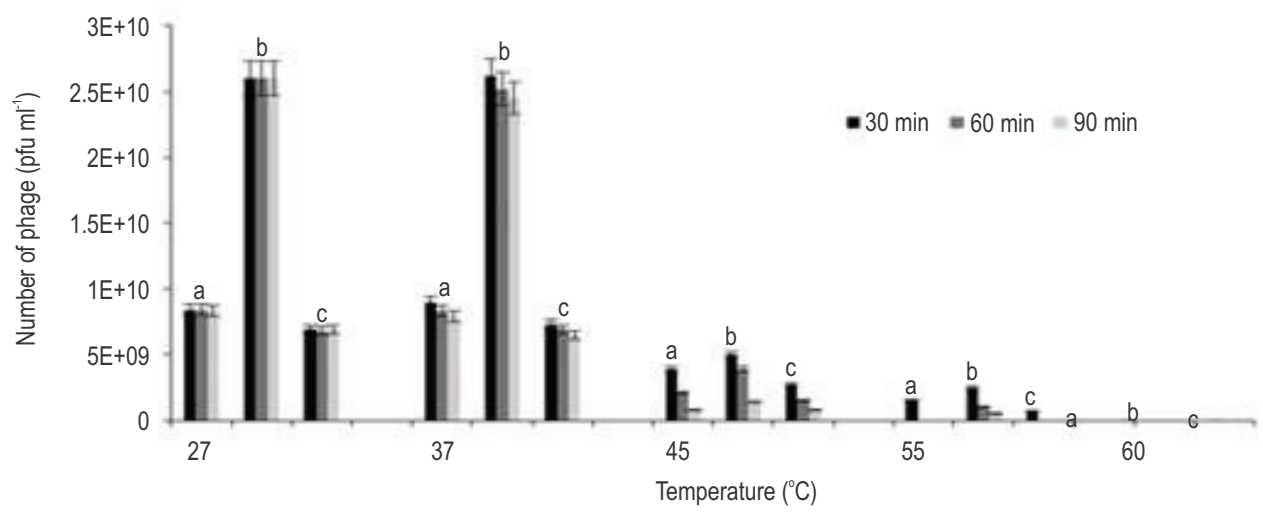

(B)

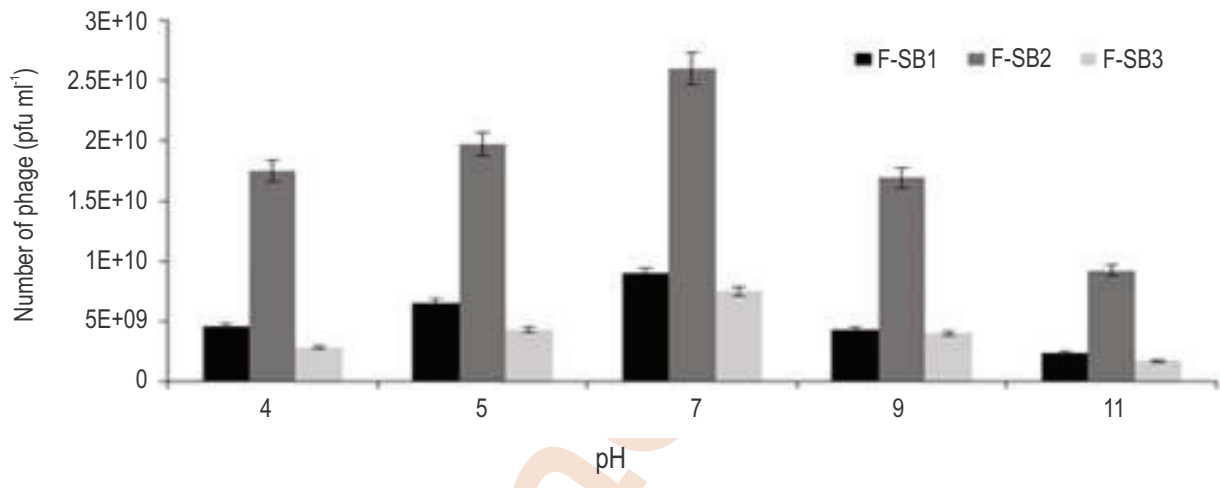

Fig. 3: Stability of lytic phages. (A) at different temperatures $\left(27^{\circ} \mathrm{C}, 37^{\circ} \mathrm{C}, 45^{\circ} \mathrm{C}, 55^{\circ} \mathrm{C}\right.$ and $60^{\circ} \mathrm{C}$ for $30 \mathrm{~min}, 60$ min and $90 \mathrm{~min}$. F-SB1 (a), F-SB2 (b) and F-SB3 (C); (B) at different pH for $30 \mathrm{~min}$. All data are means of three replicates \pm SD.

$\mathrm{ml}^{-1}, 11440 \mathrm{pfu} \mathrm{ml}^{-1}$ and $10720 \mathrm{pfu} \mathrm{ml}^{-1}$ respectively. Transmission electron microscope revealed the nano-sized isolated lytic phages which had several morphological types of head and tail (Fig. 1). Based on the morphological characteristics of the lytic phages (Fig. 1), phage F-SB1 with a long tail can be classified into family Siphoviridae, while phage F-SB2 with a tail surrounded by a sheath can be classified into Myoviridae (Ackermann, 2009). Phage F-SB3 can be classified into family Podoviridae and order Caudovirales based on the tail morphology, which was shorter compared to the other two phages (Fokine and Rossmann, 2014; Adriaenssens and Brister, 2017). The results of this research is in contrast with the results of Atterbury et al. (2007), who reported that Salmonella phages isolated from wastewater belonged to family Myoviridae and Siphoviridae.

After testing the effectiveness of phage infection, it was found that the three types of lytic phage were able to decrease the population of Salmonella spp. At $10^{4} \mathrm{pfu} \mathrm{ml}^{-1}$, all the three phages were able to reduce the host population compared to the control. The time required to decrease the host population is different for each phage. By increasing the phage concentration $\left(3 \times 10^{4} \mathrm{pfu}\right.$ $\left.\mathrm{ml}^{-1}\right)$ in the second treatment, the decrease in host population was faster than the first treatment (Fig. 2). Interestingly, based on the results of this research, the phages may be more potential in decreasing the population of Salmonella spp. than the phages used in the study of Hungaro et al. (2013), where $10^{8}-10^{9} \mathrm{pfu} \mathrm{ml}^{-1}$ concentration was used. It has been reported that phages can be used efficiently in modern biotechnology as an alternative to lyse many antibiotic resistant bacterial pathogens (Haq et al., 2012; Wittebole et al., 2013; Elbreki et al., 2014; Quiroz et al., 2016). In addition, previous researchers have reported that lytic phages can be employed as an alternative of bio-control agents to reduce contamination by $S$. enterica or S. enteritidis (Bao et al., 2011; Thung et al., 2016), EPEC K1 ${ }^{-1}$ (Arivo et al., 2016), B. pumilus (Kusmiatun et al., 2015) and foodborne pathogenic bacteria (Thung et al., 2017).

In terms of effectiveness, different morphological characteristics of lytic phages indicate that they were able to infect the bacteria with different virulence numbers as shown in 

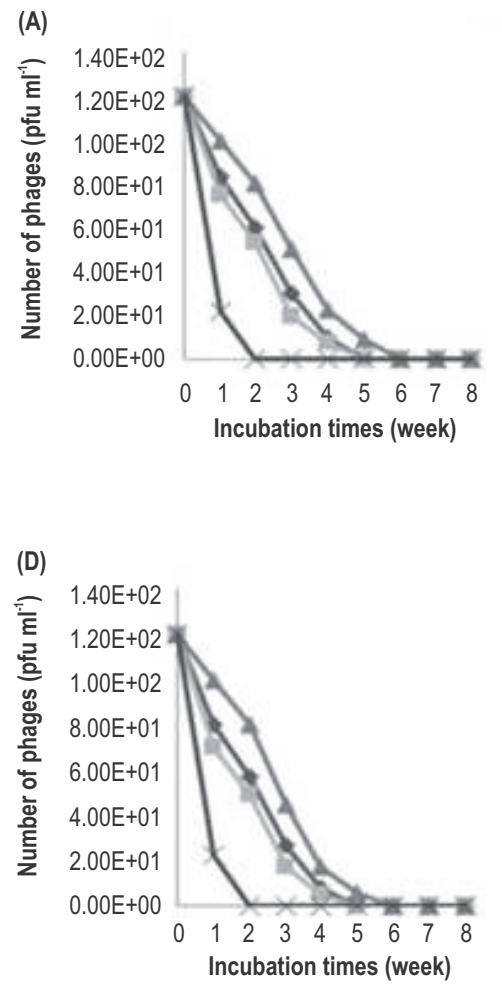
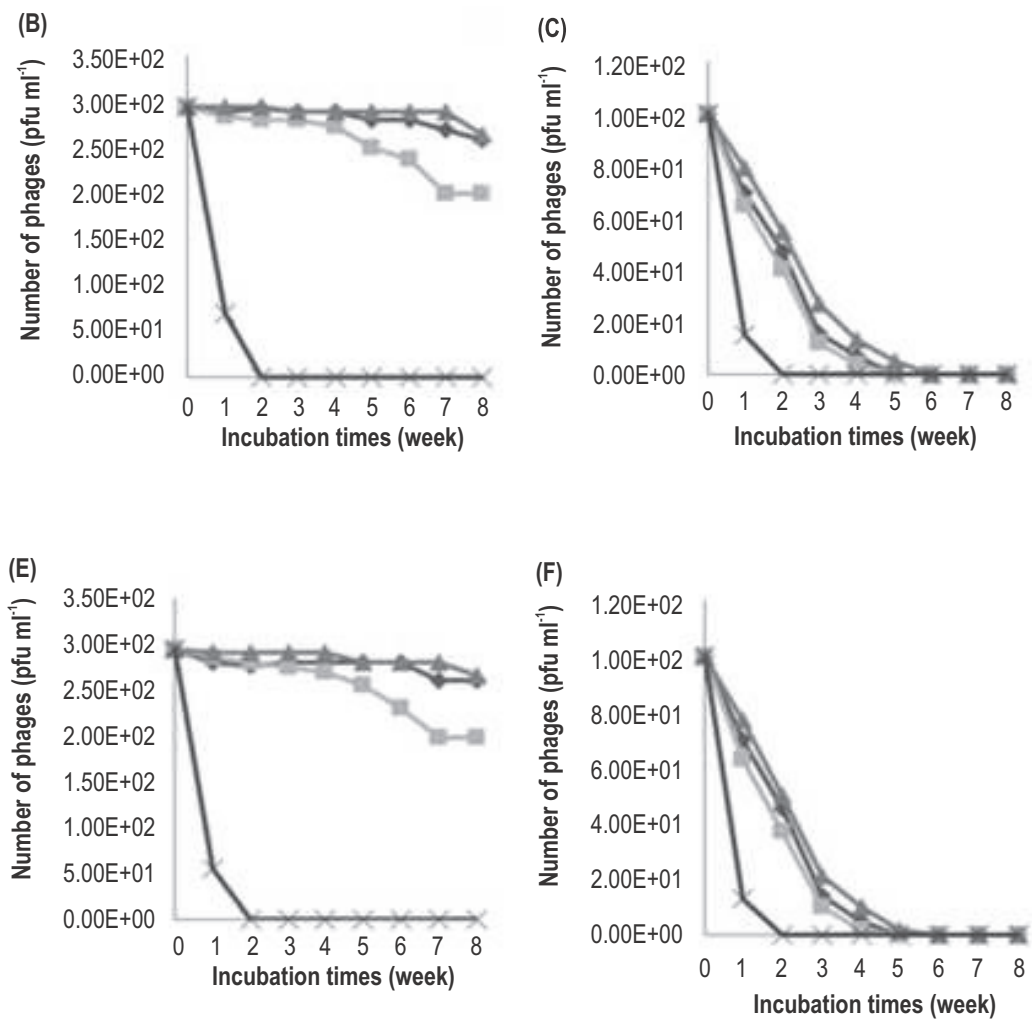
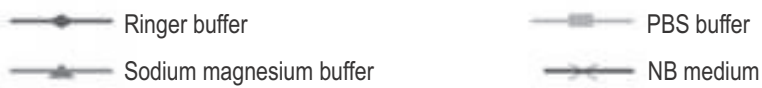

Fig. 4: Stability of lytic phages at different buffers at room temperature $27^{\circ} \mathrm{C}$; (A) F-SB1; (B) F-SB2; (C) F-SB3; at lower temperature $4{ }^{\circ} \mathrm{C}$ and (D) F-SB1; (E) F-SB2 and (F) F-SB3.

Atterbury's study. It was found that different morphological characteristics cause different virulence numbers in infecting Salmonella spp. (Atterbury et al., 2007). The difference of morphological characteristics of the phages in this study may cause difference in their ability to penetrate host cells which would result in different effectiveness. This might be one of the reasons why each phage needs different time in decreasing the host population. It is known that lytic phages have different molecular protein weights of $16-42 \mathrm{kDa}, 16-120 \mathrm{kDa}$ and $12-57 \mathrm{kDa}$, respectively. (data not shown). Phage F-SB2 had the highest protein concentration (305 ug $\left.\mathrm{ml}^{-1}\right)$, while phage F-SB1 had smaller protein concentration (268 ug ml${ }^{-1}$ ) than phage F-SB2. Phage F-SB3 had the lowest protein concentration (230 ug ml$\left.{ }^{-1}\right)$ among all phages.

In terms of stability of lytic phages, temperature plays an important role in the stability of phage protein. Some proteins can be denatured at high temperatures, even at temperatures slightly above the optimum temperature (Siang et al., 2004). The isolated
Iytic phages (F-SB1, F-SB2, and F-SB3) were stable at $27^{\circ} \mathrm{C}$ to $37^{\circ} \mathrm{C}$ after 30 min incubation, but they became unstable when the temperature is increased to $45^{\circ} \mathrm{C}, 55^{\circ} \mathrm{C}$ and $60^{\circ} \mathrm{C}$ (Fig. 3a). In addition, all phages, in this research, were stable at acidic $\mathrm{pH}$ (4-5) to neutral (6-7) pH, and pH 7 was considered as optimum (Fig. 3b).

The other physical and chemical factors that determine the stability of phage were $\mathrm{pH}$ and ion. Based on buffer assay, phage F-SB2 showed the best stability in sodium magnesium buffer at $27^{\circ} \mathrm{C}$ or $4^{\circ} \mathrm{C}$, while two other phages F-SB1 and F-SB3 showed the best stability in sodium magnesium buffer at $27^{\circ} \mathrm{C}$ (Fig. 4). The difference in phage stability is influenced by the chemical composition contained in the buffer. Therefore, the damage on structural elements such as head, tail and DNA structure changes may inactivate phage due to inappropriate (Jończyk et al., 2011).

All phages found in this research have different morphological characteristics and virulence numbers to decrease 
the Salmonella population. They were almost identical in biological characteristics and stable at $27^{\circ} \mathrm{C}-37^{\circ} \mathrm{C}$ temperature, $\mathrm{pH}$ 4-7 and sodium magnesium buffer. Therefore, this study gives information in phage application as a biocontrol agents.

\section{Acknowledgment}

This research was supported by the Ministry of Research, Technology and Higher Education of the Republic of Indonesia.

\section{References}

Ackermann, H.W.: Phage Classification and Characterization. In: (Eds.: M. R. Clokie and A. M. Kropinski), Bacteriophages Methods and Protocols. Vol. 501, p. 127. Humana Press, New York (2009).

Adriaenssens, E.M. and J.R. Brister: How to name and classify your phage: An informal guide. Viruses, 9, 1-9 (2017).

Ao, T.T., N.A. Feasey, M.A. Gordon, K.H. Keddy, F.J. Angulo and J.A. Crump: Global burden of invasive nontyphoidal Salmonella disease, 20101. Emerg. Infect. Dis., 21, 941-949 (2015).

Arivo, D., I. Rusmana and S. Budiarti: Isolation and characterization of EPEC phage from domestic waste in Indonesia. Malay. J. Microbiol., 12, 140-146(2016).

Atterbury, R.J., M.A.P. Van Bergen, F. Ortiz, M.A. Lovell, J.A. Harris, A. De Boer and P.A. Barrow: Bacteriophage therapy to reduce Salmonella colonization of broiler chickens. Appl. Environ. Microbiol., 73, 4543-4549 (2007).

Bao, H., H. Zhang and R. Wang: Isolation and characterization of bacteriophages of Salmonella enterica serovar Pullorum. Poult. Sci., 90, 2370-2377 (2011).

Baudart, J., K. Lemarchand, A. Brisabois and P. Lebaron: Diversity of Salmonella strains isolated from the aquatic environment as determined by serotyping and amplification of the ribosomal DNA spacer regions. Appl. Environ. Microbiol. Environ. Microbiol., 66, 1544-1552 (2000).

Bertelloni, F., M. Chemaly, D. Cerri, F. Le Gall and V.V. Ebani: Salmonella infection in healthy pet reptiles: Bacteriological isolation and study of some pathogenic characters. Acta Microbiol. Imm. H., 63, 203$216(2016)$

Boulani, A.R.El, Mimouni, E. Boulani and R. Mimouni: Salmonella in wastewater: Identification, antibiotic resistance and the impact on the marine environment. In: Current topics in Salmonella and salmonellosis. INTECH, World's largest Science, Technology \& Medicine Open Access Book Publisher, pp.137-148 (2017).

Budiarti, S. Y. Hirai, J. Minami, S. Katayama, T. Shimizu and A. Okabe: Adherence to HEp-2 cells and replication in macrophages of Salmonella derby of human origin. Microbiol. Immunol., 35, 111$123(1991)$.

Dickson, D.I., I.A. Chibuogwu and E.I. Maureen: Serotyping and molecular typing of Salmonella species isolated from wastewater in Nsukka, Nigeria. Afr. J. Microbiol. Res., 10, 883-889 (2016).

Dinkar, N., A.K. Sharma, A.S. Ninawe and Y. Prasad. Molecular characterization of lytic phages specific to antibiotic resistant isolates of Pseudomonas fluorescens infecting Labeo rohita and Clarias batrachus of Sub Himalayan region. J. Environ. Biol., 38, 353-360 (2017).

Doss, J., K. Culbertson, D. Hahn, J. Camacho and N. Barekzi:A review of phage therapy against bacterial pathogens of aquatic and terrestrial organisms. Viruses, 9, 1-10 (2017).

Ejo, M., L. Garedew, Z. Alebachew and W. Worku: Prevalence and antimicrobial resistance of Salmonella isolated from animal-origin food items in Gondar, Ethiopia. BioMed. Res. Int., 2016, 1-8 (2016).

Elbreki, M., R.P. Ross, C. Hill, J. O'Mahony, O. McAuliffe, A. Coffey and A. Coffey: Bacteriophages and their derivatives as biotherapeutic agents in disease prevention and treatment. J. Virus., 2014, 1-20 (2014).

Eng, S.K., P. Pusparajah, N.S. Ab Mutalib, H.L. Ser, K.G. Chan and L.J. Lee: Salmonella: A review on pathogenesis, epidemiology and antibiotic resistance. Front. Life. Sci., 8, 284-293 (2015).

Fokine, A. and M.G. Rossmann: Molecular architecture of tailed doublestranded DNA phages. Bacteriophage, 4, e28281 (2014).

Guenther, S., D. Huwyler, S. Richard and M.J. Loessner: Virulent bacteriophage for efficient biocontrol of Listeria monocytogenes in ready-to-eat foods. Appl. Environ. Microbiol., 75, 93-100 (2009).

Haq, I.U., W.N. Chaudhry, M.N. Akhtar, S. Andleeb and I. Qadri: Bacteriophages and their implications on future biotechnology: A review. Virol. J., 9, 9 (2012).

Hoelzer, K., A.I.M. Switt and M. Wiedmann: Animal contact as a source of human non-typhoidal salmonellosis. Vet. Res., 42, 34 (2011).

Hungaro, H.M., R.C.S. Mendonça, D.M. Gouvêa, M.C.D. Vanetti and C.L. Pinto de O. Use of bacteriophages to reduce Salmonella in chicken skin in comparison with chemical agents. Food Res. Int., 52, 75-81 (2013).

Jończyk, E., M. Kłak M, R. Międzybrodzki and A. Górski: The influence of external factors on bacteriophages. J. Folia. Microbiol., 56, 191200 (2011).

Julien, C.K., G. Alahou, A. Gabazé, K. Kouamé, K.K. Stephane, Y.O. Bernard and D. Mireille: The antibiotic resisting profile of Salmonella spp. isolated from the sewage of the campus of the University of Cocody, Abidjan, Côte d' Ivoire. Int. J. Trop. Dis. Health, 4, 608-620 (2014).

Kuhn, K.G., G. Falkenhorst, T.H. Ceper, T. Dalby, S. Etheberg, K. Molbak and K.A. Krogfelt: Detecting non-typhoid Salmonella in humans by ELISAs: a literature review. J. Med. Microbiol., 61, 1-7 (2012).

Kurek A.J. T. Gasior, B. N. Falenczyk, S. Bloch, A. Dydeca, G. Topka, A Necel, M. Jakubowska-Deredas, M. Narajczyk, M. Richert, A Mieszkowska, B. Wrobel, G. Wegrzyn and A. Wegrzyn: Biodiversity of bacteriophages: morphological and biological properties of a large group of phages isolated from urban sewage. Sci. Reports., 6, 34338 (2016)

Kusmiatun, A., I. Rusmana and S. Budiarti: Characterization of bacteriophage specific to Bacillus pumilus from Ciapus River in Bogor, West Java, Indonesia. HAYATI J. Biosci., 22, 27-33 (2015).

Kusumaningrum, H. D., Suliantari and R. Dewanti-Hariyadi: Multidrug resistance among different serotypes of Salmonella isolates from fresh products in indonesia. Int. Food Res. J., 19, 57-63 (2012).

Laemmli, U.K: Cleavage of structural proteins during the assembly of the head of bacteriophage T4. Nature, 227, 680-685 (1970).

Majowicz, S.E., J. Musto, E. Scallan, F.J. Angulo, M. Kirk, S.J. O'Brien and R.M. Hoekstra: The global burden of nontyphoidal Salmonella gastroenteritis. Clin. Infect. Dis., 50, 882-889 (2010).

Matias, C.A.R., I.A. Pereira, M. Araújo, dos S. de, A.F.M. Santos, R.P. Lopes, S. Christakis and S. Siciliano: Characteristics of Salmonella spp. isolated from wild birds confiscated in illegal trade markets, Rio de Janeiro, Brazil. BioMed. Res. Int., 2016, 1-7 (2015).

Miyakawa, S., K. Takahashi, M. Hattori, K. Itoh, T. Kurazono and F. Amano: Outbreak of Salmonella oranienburg infection in Japan. J. Environ. Biol., 27, 157-158 (2006).

Nugroho, P.D., S. Budiarti and I. Rusmana: Characterization of Iytic phage Staphylococcus aureus from dairy farm cows in Indonesia. Int. J. PharmTech. Res., 9, 10-18 (2016).

Prasad, Y., Arpana, D. Kumar and A.K. Sharma: Lytic bacteriophages 
specific to Flavobacterium columnare rescue catfish, Clarias batrachus (Linn.) from columnaris disease. J. Environ. Biol., 32, 161-168 (2011)

Quiroz, E., J. Recalde, M.T. Arias, R. Seqqat, C. Vinueza and L. Ayala: Isolation of lytic bacteriophages for nanobiocontrol of pathogenic and antibiotic resistant Salmonella present in poultry in Ecuador. Biol. Med., 8, 1-6 (2016).

Sartika, D., S. Budiarti and M. Sudarwanto. Phage FR38 treatment on sprague dawley rat inferred from blood parameters and organ systems. HAYATI J. Biosci., 19, 131-136 (2012).

Siang, T.W., P. Ramanujam and S. Nathan: Effect pH and temperature on the binding of a fusion phage to newcastle disease virus. $\mathrm{J}$. Biochem., 9, 35-37 (2004).

Thung, Tze Young, JMKJ Premarathne, W.S. Chang, Y.Y. Loo, Y.Z. Chin, C.H. Kuan, C.W. Tan, D.F. Basri, C.W.J.W.M. Radzi and S. Radu: Use of a lytic bacteriophage to control Salmonella enteritidis in retail food. Food Sci. Technol., 4, 1-4 (2016).

Thung, T.Y., B.M.F. Siti Norshafawatie, J.M.K.J.K. Premarathne, W.S. Chang, Y.Y. Loo, C.H. Kuan and R. Son: Isolation of food-borne pathogen bacteriophages from retail food and environmental sewage. Int. Food Res. J., 24, 450-454 (2017).

Tjanadi, P., M. Lesmana, D. Subekti, N. Machpud, S. Komalarini, W. Santoso and B. A. Oyofo: Antimicrobial resistance of bacterial pathogens associated with diarrheal patients in Indonesia. Am. J. Trop. Med. Hyg., 68, 666-670 (2003).

Toroglu, S., E. Toroglu, S. Dincer, C. Kara and M. Kertmen: Resistances of antibiotics and heavy metals in Enterobacteriaceae spp. isolated from gills and intestines of Achanthobrama marmid (Heckel, 1843) from Sir Dam lake Turkey. J. Environ. Biol., 30, 2331 (2009).

Turki, Y., H. Ouzari, I. Mehri, Ammar, A. Ben and A. Hassen: Evaluation of a cocktail of three bacteriophages for the biocontrol of Salmonella of wastewater. Food Res. Int., 45, 1099-1105 (2012).

Wittebole, X., S. De Roock and S.M. Opal: A historical overview of bacteriophage therapy as an alternative to antibiotics for the treatment of bacterial pathogens. Virulence, 5, 226-235 (2013).

Zuber, S., C. Boissin-Delaporte, L. Michot, C. Iversen, B. Diep, H. Brüssow and P. Breeuwer: Decreasing Enterobacter sakazakii (Cronobacter spp.) food contamination level with bacteriophages: Prospects and problems. Microbial. Biotechnol., 1,532-543(2008). 